Original Research Article

\title{
Malacological survey in a bottle of water: A comparative study between manual sampling and environmental DNA metabarcoding approaches
}

\author{
Stephen Mulero a, *, Eve Toulza a , Anaïs Loisier a , Meryl Zimmerman a \\ Jean-François Allienne a, Joséphine Foata ${ }^{\mathrm{b}}$, Yann Quilichini ${ }^{\mathrm{b}}$, \\ Jean-Pierre Pointier ${ }^{c}$, Olivier Rey ${ }^{\mathrm{a}, 1}$, Jérôme Boissier ${ }^{\mathrm{a}, 1}$ \\ a University of Perpignan, IHPE UMR 5244, CNRS, IFREMER, Univ. Montpellier, F-66860, Perpignan, France \\ ${ }^{\mathrm{b}}$ UMR SPE 6134, CNRS - Università di Corsica Pascal Paoli, 20250, Corte, Corsica, France \\ c PSL University, USR3278 CRIOBE EPHE-CNRS-UPVD, F-66860, Perpignan, France
}

\section{A R T I C L E I N F O}

\section{Article history:}

Received 18 June 2020

Received in revised form 29 November 2020

Accepted 19 December 2020

\section{Keywords:}

Biomonitoring

Corsica

Environmental DNA

Malacology

Metabarcoding

Snail communities

\begin{abstract}
A B S T R A C T
To assess the effect of anthropogenic activities on ecosystems, it is of prime importance to develop new tools enabling a rapid characterization of ecological communities. Freshwater ecosystems are particularly impacted and threatened by human activities and need thorough attention to preserve their biodiversity and the ecological services they provide. Studying such ecosystems is generally difficult because the associated organisms are hard to sample and to monitor. We present a ready-to-use environmental metabarcoding protocol to characterize and monitor the freshwater gastropods communities from water samples. The efficiency of this new tool was compared to a classical malacological survey at 19 sampled sites from 10 distinct rivers distributed over Corsica Island (France). From a single water sample, our eDNA monitoring tool provided a faithful characterization of the local malacofauna compared to the results obtained from the classical malacological survey, with $97.1 \%$ of species detection confirmed by both methods. The present tool successfully detected the 11 freshwater snail species previously reported in Corsica by malacological survey but was limited at the genus level for some species. Moreover, our malacological survey allowed an update of the local distribution of a wide diversity of freshwater snails including invasive species (i.e. Potamopyrgus antipodarum and Physa acuta) as well as snail hosts of pathogens of medical and veterinary importance (i.e. Bulinus truncatus and Galba truncatula). These results strengthened a previous hypothesis of an eventual competitive interaction between $B$. truncatus and $P$. antipodarum that could limit the endemization of the uro-genital bilharziasis in Corsica.
\end{abstract}

(C) 2020 The Author(s). Published by Elsevier B.V. This is an open access article under the CC BY license (http://creativecommons.org/licenses/by/4.0/).

\footnotetext{
* Corresponding author. Université de Perpignan Via Domitia, 52 Avenue Paul Alduy, 66860, Perpignan cedex 9, France.

E-mail addresses: stephen.mulero@outlook.com (S. Mulero), eve.toulza@univ-perp.fr (E. Toulza), anais.loisier@gmail.com (A. Loisier), zimmermann. meryl@gmail.com (M. Zimmerman), allienne@univ-perp.fr (J.-F. Allienne), foata_j@univ-corse.fr (J. Foata), quilichini_y@univ-corse.fr (Y. Quilichini), pointier@univ-perp.fr (J.-P. Pointier), olivier.rey@univ-perp.fr (O. Rey), boissier@univ-perp.fr (J. Boissier).

${ }^{1}$ Both authors contributed equally to the study.
} 


\section{Introduction}

Anthropogenic activities contribute to habitat fragmentation (Strayer and Dudgeon, 2010) or pollution (Blettler et al., 2018) that have adverse effects on ecosystems (Parmesan and Yohe, 2003), including an important decrease of biodiversity (Waldron et al., 2017). Freshwater ecosystems appear to be particularly threatened by human activities leading to local species extinction (Blettler et al., 2018). According to the IUCN Red list, 46\% of these ecosystems worldwide are endangered or vulnerable (Janssen et al., 2016). These ecosystems host $10 \%$ of all known species despite representing only $0.8 \%$ of the Earth's surface (Balian et al., 2008; Strayer and Dudgeon, 2010). They also provide important ecological services for the development of human populations (Carpenter et al., 2011).

Among freshwater species, gastropods have received particular attention for several reasons. First, they are suffering massive extinction notably due to habitat loss/degradation, the introduction of alien species and, in some cases, overexploitation (Bouchet et al., 1999; Johnson et al., 2013; Lydeard et al., 2004; Strong et al., 2007). Second, they play a key role in the functioning of most freshwater habitats. They are involved in the cycle of several biochemicals especially nitrogen (Hill and Griffiths, 2017) and are the prey of several fishes (Dillon, 2000b). Freshwater snails are also effective shredders and processors of vegetal matter in freshwater environment hence contributing to local matter and nutrient cycling (Dillon, 2000a). Finally, several freshwater gastropods are of medical or veterinary importance as they constitute intermediate hosts for several pathogens (e.g. Trematoda) (Lu et al., 2018). Under the ongoing global changes, these diseases are currently (re-)emerging worldwide at an alarming rate (Jones et al., 2008; Kincaid-Smith et al., 2017). Hence, monitoring these snail species is crucial to address risk maps and thus prevent the transmission of these infectious diseases to nearby human and animal populations (Mulero et al., 2020; Jones et al., 2015).

Unfortunately, the monitoring of freshwater snails is challenging because: (i) there is no standardized monitoring protocol (Tallarico, 2016); (ii) their populations are spatially and temporally highly dynamic (Lamy et al., 2012); and (iii) classical methods used to collect and to identify snail species are time-consuming, laborious and need malacological expertise (Vinarski and Kramarenko, 2015). In this context, the use of more sensitive molecular detection approaches such as environmental DNA (eDNA) are promising (Bohmann et al., 2014).

According to Taberlet et al., environmental DNA is a "complex mixture of genomic DNA from many different organisms found in an environmental sample" (Taberlet et al., 2012, 2018). This complex and heterogeneous community of DNA fragments originating from all surrounding organisms is either free in the environment or associated with organic or inorganic particles in water, soil or atmosphere (Pedersen et al., 2015; Taberlet et al., 2012). The use of eDNA approaches for monitoring targeted snail species already exist to detect invasive species such as Potamopyrgus antipodarum and Crepidula fornicata (Goldberg et al., 2013; Miralles et al., 2019; Clusa et al., 2017); or gastropod species that transmit parasitic diseases such as Galba truncatula, Austropeplea tomentosa, Bulinus truncatus and Oncomelania hupensis (Jones et al., 2018; Mulero et al., 2020; Fornillos et al., 2019). In such a biodiversity assessment context, only one eDNA tool have very recently been developed to characterize communities of freshwater bivalves (Prié et al., 2020). However, still is lacking a general eDNA-based tool to characterize the communities of freshwater gastropods.

To fill this gap, we here present the development of a ready-to-use eDNA-based diagnostic protocol for monitoring freshwater snail communities and its application in Corsica island. This study is constructed around four objectives (i) Developing a step-by-step environmental metabarcoding protocol. (ii) Comparing this protocol with a classical visual malacological survey approach in 19 sites from 10 rivers across Corsica Island (France). (iii) Providing an updated vision of the local malacofauna at the Island scale with focus on both invasive species and species with medical importance. (iv) Discussing the pros and cons of the emerging eDNA approaches compared to classical prospecting methods.

\section{Materials and methods}

\subsection{Malacological survey and water sampling}

The field work was conducted during August and September 2018 in the Corsica Island. This summer end period fulfil optimal conditions for the presence of freshwater snails populations that reach their highest density (Kincaid-Smith et al., 2017). Overall, the sampling campaign consisting of both a water sampling for eDNA and a malacological survey were performed at 23 sites distributed over 13 different rivers (Fig. 1). These sites are known for human recreational activities and are annually monitored by the French agency “Agence Régionale de Santé” de Corse (ARS, 2019).

\subsubsection{Water sampling}

Water samples for subsequent eDNA analyses were collected before the malacological survey and following a previously optimized protocol (Mulero et al., 2020). At each sampling site, $3 \mathrm{~L}$ of water were filtered in a single position from the river streambed just under the water surface. The water was collected downstream the prospected site to capture flowing eDNA from upstream transects, covering potentially the overall gastropod communities at a given site. Water filtrations were achieved using a sterile filtration unit with a $0.45 \mu \mathrm{m}$ PES membrane of $90 \mathrm{~mm}$ diameter (VWR PES filter unit $1 \mathrm{~L}$, model 514 0301) connected to a manual vacuum pump (Mityvac model MV8500). Afterwards, each filtration membrane was immediately stored in a $50 \mathrm{~mL}$ tube with a sterile Longmire buffer (Longmire et al., 1997). Membranes were then stored in a dark cold room at $4{ }^{\circ} \mathrm{C}$ until subsequent molecular analyses. During all the sampling process, precautions were taken to avoid any 


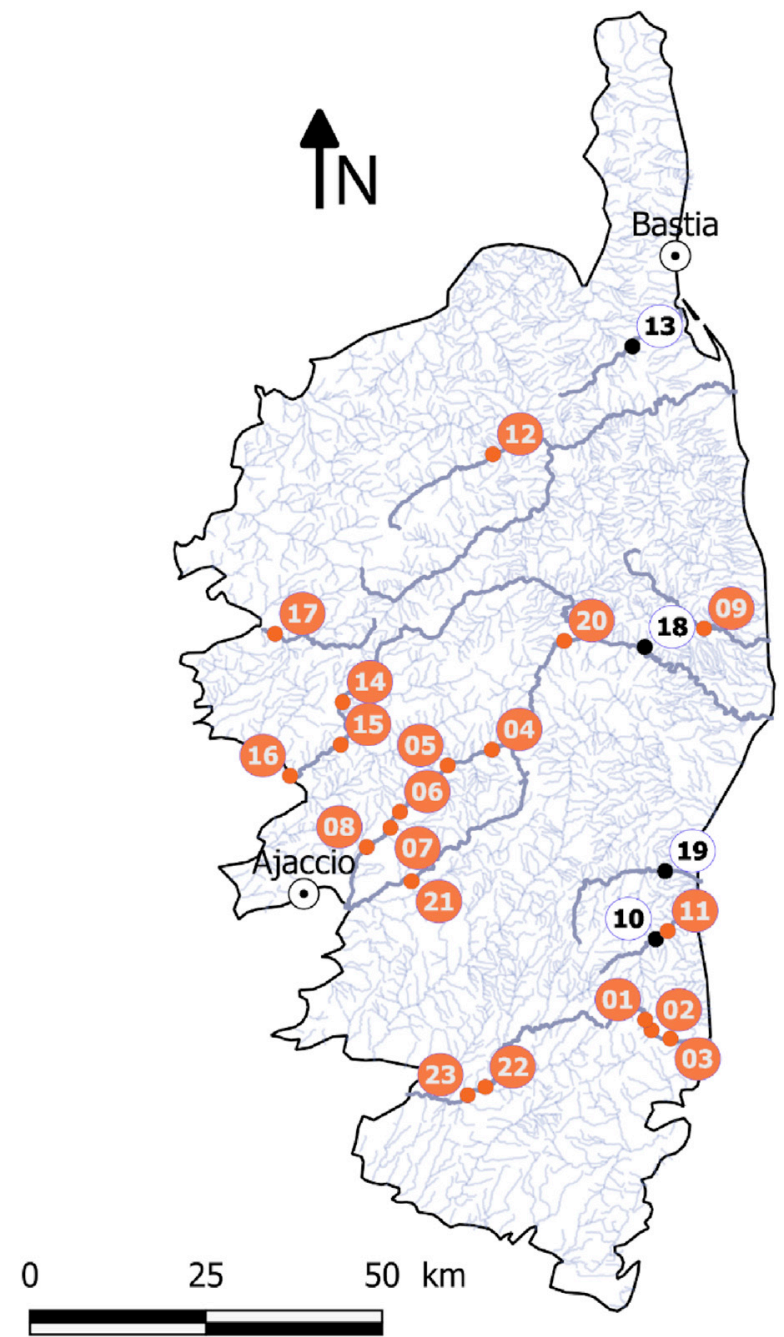

Fig. 1. Map referencing the 23 sites prospected across Corsica Island for malacological survey and for water eDNA sampling. All these sites are lotic and distributed among 13 different rivers (darker lines). These sites are annually monitored by the French agency ARS, coordinates and environmental variables available upon request. The sites in black were sampled but removed from the analysis due to potential DNA contaminations (see text for details).

contamination (Taberlet et al., 2012): operators used disposable sterile gloves and all reusable materials (i.e. scissors and forceps) were decontaminated before and after each site by successively placing instruments in a $10 \%$ bleach bath, in a $90 \%$ ethanol bath and then in a DNA AWAYTM bath (Thermo Scientific) finalized by a flame sterilization (Taberlet et al., 2012).

\subsubsection{Malacological survey}

At each site, the malacological survey was achieved along a total of $300 \mathrm{~m}$ by the same operators. Three transects of $50 \mathrm{~m}$ (downstream, at the referenced site and upstream) were prospected along the two shores of the river ( $3 \times 2$ transects). Within each transect, all freshwater snails were sampled manually or by scooping the grass on the water bench using a colander. Snails were then grouped according to their morphology and taxonomically identified at least at the genus, at best at the species level based on their morphological traits. The number of individuals of each species was semi-quantitatively estimated. If more than 100 snails were collected, we have attributed a ">100" score to the given species. At each site, GPS coordinates and several variables were collected including: the sampling day, the half day of sampling (i.e. A.M. or P.M.), water temperature \& $\mathrm{pH}$, water flow and altitude.

\subsection{Molecular approaches}

All pre-PCR molecular steps were performed under a sterile PCR hood decontaminated before and after each use as follow: the working surface was successively washed using $90 \%$ ethanol, $10 \%$ bleach and a DNA AWAYTM solution (Thermo 
Scientific ${ }^{\mathrm{TM}}$ ) and then exposed to UV light for $30 \mathrm{~min}$. The reusable materials were decontaminated following the same protocol as for the field sampling and treated under UV exposure for $30 \mathrm{~min}$.

\subsubsection{DNA extractions}

Total eDNA from each membrane was extracted using the DNeasy® Blood \& Tissue kit (QIAGEN) following an adapted protocol (Mulero et al., 2020). Briefly, membranes were subdivided into four equal parts to allow the use of $2 \mathrm{ml}$ microcentrifuge tubes, these four parts were individually lysed at $65{ }^{\circ} \mathrm{C}$ for $1 \mathrm{~h}$ in a solution containing $567 \mu \mathrm{l}$ of ATL buffers and $63 \mu \mathrm{l}$ of proteinase $\mathrm{K}$ solution. Then a solution containing $630 \mu \mathrm{l}$ of AL buffers and $630 \mu \mathrm{l}$ of $100 \%$ ethanol was added in each tube. The remaining steps of the protocol were performed following the manufacturer instructions, except for that DNA was ultimately eluted in $100 \mu \mathrm{l}(2 \times 50 \mu \mathrm{l})$ of AE buffer pre-heated to $65{ }^{\circ} \mathrm{C}$. The resulting DNA extracts were then preserved at $-20{ }^{\circ} \mathrm{C}$ until subsequent steps.

In parallel, DNA was extracted from one individual of each of the 11 snail species collected during the malacological survey to produce a synthetic "mock community". To this aim, we used the E.Z.N.A. ${ }^{\circledR}$ Tissue DNA kit (OMEGA bio-tek, Inc) following the "tissue protocol". These snail DNA extractions were used as positive PCR and sequencing controls in the following steps.

To refine the molecular species assignations obtained from subsequent NGS analyses, we sequenced a 16S rRNA region for six snail species collected in Corsica. The 16Sbr-H primers were used following the PCR conditions described in (Saito et al., 2018). The resulting amplicons contain the barcode region used for the metabarcoding. The PCR products were then sequenced on an ABI 3730xl sequencer at the GenoScreen platform (Lille, France). Sequences were obtained for Ancylus fluviatilis (MT361136), Gyraulus sp. (MT361134), Physa acuta (MT361133), Pisidium casertanum (MT361132), Theodoxus fluviatilis (MT361131) and Galba truncatula (MT361135).

\subsubsection{PCR primers}

The primer pair used in this study (Gast01) was previously developed and tested in silico (Taberlet et al., 2018) but never tested and/or applied for empirical purposes. These primers target a 60-70 bp fragment of 16S mitochondrial rRNA using the Gast01F ( $5^{\prime}$ CCGGTCTGAACTCAGATCA 3') and the Gast01R (5' TTTGTGACCTCGATGTTGGA 3') primer pair. Based on their in silico analyses, these primers theoretically amplify at least 1280 species distributed among 456 genera, mainly related to Gastropoda. In our study, we first validated that these primers were able to produce a size-expected amplicon using qPCR for the 11 snail species collected during the malacological survey and eight additional snail species from previous field works (Table 1). These 19 DNA extracts were amplified by qPCR on a LightCycler ${ }^{R} 480$ qPCR device following the same protocol as for the first PCR step of the library preparation, see 2.2.3 below.

\subsubsection{Library preparation and MiSeq amplicon sequencing}

Five negative controls and six positive controls were processed along with the environmental samples. Negative extraction controls consisted in ultrapure water samples processed following the same DNA extraction protocol as for the filtration membranes in each extraction runs $(\mathrm{N}=2)$. PCR negative controls consisted in PCR reactions performed using water as template in each PCR run $(\mathrm{N}=3)$. Positive controls consisted in two categories of mock communities. The first category consisted in an equimolar pool of 12 DNA extracts obtained from individuals of each snail species identified in Corsica and

Table 1

Snail species used for assessing the detection range of the Gast01 PCR primers in vitro.

\begin{tabular}{|c|c|c|c|c|}
\hline Snail species & Origin & Date & Provided by & Average headcount per site \\
\hline Bulinus forskalii & South-Africa & 2017 & Huyse T., KU Leuven, Belgium & - \\
\hline Bulinus globosus & Senegal & 2012 & Huyse T., KU Leuven, Belgium & - \\
\hline Bulinus africanus & South-Africa & 2017 & Huyse T., KU Leuven, Belgium & - \\
\hline Radix natalensis ${ }^{\mathrm{a}, \mathrm{b}}$ & South-Africa & 2017 & Huyse T., KU Leuven, Belgium & - \\
\hline Galba schirazensis ${ }^{\mathrm{a}, \mathrm{b}}$ & Cuba & 2013 & Hurtrez-Boussès S., IRD Montpellier, France & - \\
\hline Galba cubensis ${ }^{\mathrm{a}, \mathrm{b}}$ & Cuba & 2013 & Hurtrez-Boussès S., IRD Montpellier, France & - \\
\hline Pseudosuccinea columella ${ }^{\mathrm{a}, \mathrm{b}}$ & France & 2011 & Hurtrez-Boussès S., IRD Montpellier, France & - \\
\hline Biomphalaria glabrata ${ }^{\mathrm{a}, \mathrm{b}}$ & Brazil & 2018 & & - \\
\hline Bulinus truncatus ${ }^{\mathrm{a}, \mathrm{b}}$ & Corsica, France & 2018 & & $2.28( \pm 13.95)$ from 0 to $>100$ \\
\hline Bithynia tentaculata $^{\mathrm{b}}$ & Corsica, France & 2018 & & $\mathbf{0 . 0 2}( \pm 0.28)$ from 0 to 3 \\
\hline Radix balthica ${ }^{\mathrm{b}}$ & Corsica, France & 2018 & & $\mathbf{0 . 1 1}( \pm 1.21)$ from 0 to 13 \\
\hline Ancylus fluviatilis ${ }^{\mathrm{a}, \mathrm{b}}$ & Corsica, France & 2018 & & $26.68( \pm 40.53)$ from 0 to $>100$ \\
\hline Galba truncatula & Corsica, France & 2018 & & $\mathbf{0 . 0 6}( \pm 0.38)$ from 0 to 3 \\
\hline Gyraulus laevis ${ }^{\mathrm{a}, \mathrm{b}}$ & Corsica, France & 2018 & & $\mathbf{0 . 0 6}( \pm 0.34)$ from 0 to 3 \\
\hline Gyraulus sp. ${ }^{\mathrm{a}, \mathrm{b}}$ & Corsica, France & 2018 & & $2.99( \pm 8.66)$ from 0 to 50 \\
\hline Physa acuta & Corsica, France & 2018 & & $17.38( \pm 34.29)$ from 0 to $>100$ \\
\hline Potamopyrgus antipodarum ${ }^{\mathrm{a}, \mathrm{b}}$ & Corsica, France & 2018 & & $48.03( \pm 46.38)$ from 0 to $>100$ \\
\hline Pisidium casertanum ${ }^{\mathrm{a}, \mathrm{b}}$ & Corsica, France & 2018 & & $1.45( \pm 7.10)$ from 0 to 50 \\
\hline Theodoxus fluviatilis $^{\mathrm{b}}$ & Corsica, France & 2018 & & $0.87( \pm 5.26)$ from 0 to 50 \\
\hline
\end{tabular}

a DNA extracts used for the preparation of equimolar pools of DNA $(\mathrm{N}=12)$.

b DNA extracts used for the preparation of equimolar pools of PCR products $(\mathrm{N}=16)$. The displayed median headcount for each species reported by the malacological survey consider the six measure units conducted on each sites as separate values. 
during previous field missions (Table 1). These mock communities are useful to detect PCR competition among different snail species. The second category of mock community consisted in pooling an equimolar quantity of PCR products individually obtained from 16 freshwater snail species (i.e. including the 11 identified snail species collected in Corsica and five additional non-endemic species bred in our laboratory). These controls are useful to detect possible biases during the sequencing process.

Individual libraries were generated for each membrane section of the 23 filtration membranes and for each control, hence, representing a total of 103 libraries ( $23 \times 4=92$ eDNA samples +11 controls). NGS libraries were prepared following the Illumina two-step PCR protocol, using mitochondrial 16S primers with Illumina adapters for the first locus-specific PCR. Both PCR were performed using the NEBNext ${ }^{\circledR}$ Ultra ${ }^{\mathrm{TM}}$ II Q5 ${ }^{\circledR}$ Master Mix M0544L (NEW ENGLAND BioLabs, USA). The first PCR reactions were performed in a final volume of $35 \mu \mathrm{l}$ containing $3.5 \mu \mathrm{l}$ of extracted DNA (concentrations ranging from 0.05 ng/ $\mu \mathrm{l}$ to $8.52 \mathrm{ng} / \mu \mathrm{l}$ ), $17.5 \mu \mathrm{l}$ of $2 \mathrm{X}$ Q5 Master Mix and $14 \mu \mathrm{l}$ of indexed primer mix (final concentration $0.4 \mu \mathrm{M}$ ) and ran on a Techne TC-PLUS thermal cycler PCR device (Techne, UK) using the following program: $98{ }^{\circ} \mathrm{C}$ for $30 \mathrm{~s}$ followed by $40 \mathrm{cycles}$ at $98{ }^{\circ} \mathrm{C}$ for $10 \mathrm{~s}, 55^{\circ} \mathrm{C}$ for $20 \mathrm{~s}, 65^{\circ} \mathrm{C}$ for $8 \mathrm{~s}$ and a final elongation step of $2 \mathrm{~min}$ at $65^{\circ} \mathrm{C}$. At this point, all PCR products were checked on a $2.5 \%$ agarose gel stained with ethidium bromide after electrophoresis.

The PCR products were individually indexed in the second PCR step consisting in eight cycles using the Nextera ${ }^{\mathrm{TM}}$ XT Index (Illumina, San Diego, USA) following the manufacturer's instructions. Finally, the libraries were normalized using SequalPrep $^{\mathrm{TM}}$ plates (Thermo Fischer Scientific, USA) before pooling. The pooled libraries were then purified following the JetSeq ${ }^{\mathrm{TM}}$ Clean protocol (Bioline, UK), checked on a Bioanalyzer High Sensitivity DNA kit (Agilent, USA) and quantified using a Qubit fluorometric quantification (Thermo Fisher Scientific, USA). Paired-end sequencing $(2 \times 250$ cycles) was performed with a MiSeq Reagent Kit v2 on an Illumina MiSeq ${ }^{\mathrm{TM}}$ instrument at the Bio-Environnement platform (University of Perpignan Via Domitia, France).

\subsection{Data analyses}

\subsubsection{Bioinformatic pipeline}

The resulting amplicon sequence dataset was processed using the Find Rapidly OTUs with Galaxy Solution (FROGS) pipeline implemented in Galaxy (Escudie et al., 2018) at the Genotoul platform (Toulouse, France). (i) The amplicon dataset was first pre-processed, according to Gast01 primer specificities (i.e. amplicon size of 60-70 bp), we filtered out the sequences so as to keep amplicon sizes from 95 to 120 nucleotides (i.e. corresponding to the size of the targeted amplicon with Illumina adapters). (ii) The sequences kept were next clustered in operational taxonomic units (OTUs) using the swarm algorithm and using denoising and an aggregation distance of three nucleotides. (iii) The dataset was filtered out for chimeras using VSEARCH (Rognes et al., 2016). Singletons and underrepresented clusters (i.e. <10 sequences) were removed as they correspond most likely to PCR error than rare sequences (Valentini et al., 2016; Prié et al., 2020). (iv) Each OTU was assigned to a species or taxon through a two-step MEGABLAST affiliation procedure. The first MEGABLAST analysis was restricted to Mollusca species. The second MEGABLAST analysis was performed without restricting parameters to check the robustness of the previous affiliations. The 10 best hits were kept for subsequent analysis. ( $v$ ) The resulting OTUs were filtered following two criteria: first, only OTUs presenting a minimal blast coverage of $84 \%$ of amplicon length were kept; second, only OTUs presenting a pairwise identity above $89 \%$ with the affiliated sequence were kept, these thresholds are based on previously published protocols (Macher et al., 2018) and on intraspecific sequences variations among snail strains. The remaining OTUs were considered as "unassigned".

Lastly, to confirm that a given OTU was detected in a specific sample, we have adapted our validation criteria depending on OTUs abundances. An abundant OTU (i.e. $\geq 1000$ copies considering all the samples) was considered present in a specific membrane when reaching at least 10 copies (overall the four membrane sections). Regarding poorly abundant OTU (i.e. < 1000 copies considering all the samples), we considered a sample positive if four or more copies of such OTU were distributed among two quarters of a same membrane.

\section{Results}

\subsection{Malacological survey}

Overall, 11 distinct freshwater snail species were identified among the 23 sampled sites (Table 1S1). These species were already registered in Corsica (INPN, 2020; IUCN, 2020) where 18 species of freshwater mollusk have been described so far, five of which inhabiting lentic ecosystems (Table S1) and (Mouthon, 1982; INPN, 2020). The species richness ranged from one (site 4) to six (site 23). The most common species was P. antipodarum (22/23 sites) and the rarest were $T$. fluviatilis (1/23 sites) and Bithynia tentaculata ( 3 individuals at site 13). Among the species identified, two are invasive (i.e. P. antipodarum and P. acuta) and two are intermediate hosts for Human and livestock parasites (i.e. B. truncatus and G. truncatula). Our semi-quantitative approach showed that $P$. antipodarum and $A$. fluviatilis were the most abundant species with $48.03 \pm 46.38$ and $26.68 \pm 40.53$ individuals, respectively (Table 1 ). 


\subsection{Molecular results}

Over the 19 snail DNA extracts tested in qPCR with metabarcoding primers (Table 1), all but $P$. casertanum were positive. Regarding the equimolar pools of DNA, whatever pre- (Fig. S2a) or post-PCR (Fig. S2b) the sequencing of equimolar pools gave a number of reads for each species fitting to the expected ratio. This was higher evenness for post-PCR pools.

Despite all our precautions, four among the 23 eDNA water samples (from sites 10,13, 18 and 19- see Fig. 1) were possibly contaminated and were thus discarded. In fact, amplicons corresponding of A. fluviatilis, G. truncatula and B. truncatus were found in the negative PCR controls associated with these samples. Hence, the subsequent metabarcoding data analysis was performed on the 19 remaining sites distributed over 10 rivers of Corsica.

Excluding the four contaminated sites, the whole sequencing (controls + field samples) generated more than $14 \mathrm{M}$ of clusters with an average of 97,000 sequences per library. After analyses, $8.7 \mathrm{M}$ of sequences were affiliated (Fig. 2). These sequences were grouped among 488 OTUs with 43 OTUs corresponding to Mollusca species. After removing the sequences from control samples, on the 7,290,067 remaining sequences, 6\% $(445,638)$ were affiliated to Mollusca, including 424,580 sequences affiliated to Gastropoda; $10 \%(715,308)$ were unaffiliated and $84 \%(6,129,121)$ were affiliated to non-mollusk species (Fig. 2). Whatever the taxonomic group, the OTU affiliations were generally limited to the genus and rarely reached the species level (e.g. only four out of 11 freshwater snail species found by metabarcoding were affiliated to a single species name). However, the 16S sequences obtained from snail DNA extracts collected in Corsica, allowed to recover the corresponding species name for major Mollusca OTUs. All the genus or species detected using eDNA corresponded to species already identified in Corsica and no new genus was detected compared to our malacological survey. Hence, considering all prospected sites, we detected $61.1 \%$ (11/18) of historically known freshwater mollusks in Corsica and 84.6\% (11/13) of species occurring in lotic systems (Table S1) and (INPN, 2020; Mouthon, 1982). The detected snail species belong to three subclasses of the Gastropoda (i.e. Neritimorpha, Caenogastropoda, and Heterobranchia) (Fig. 3). The non-detected subclasses (e.g. Vetigastropoda and Patellogastropoda) are related to marine snail species. Beyond gastropods species, the present protocol allowed the detection of the bivalve $P$. casertanum.

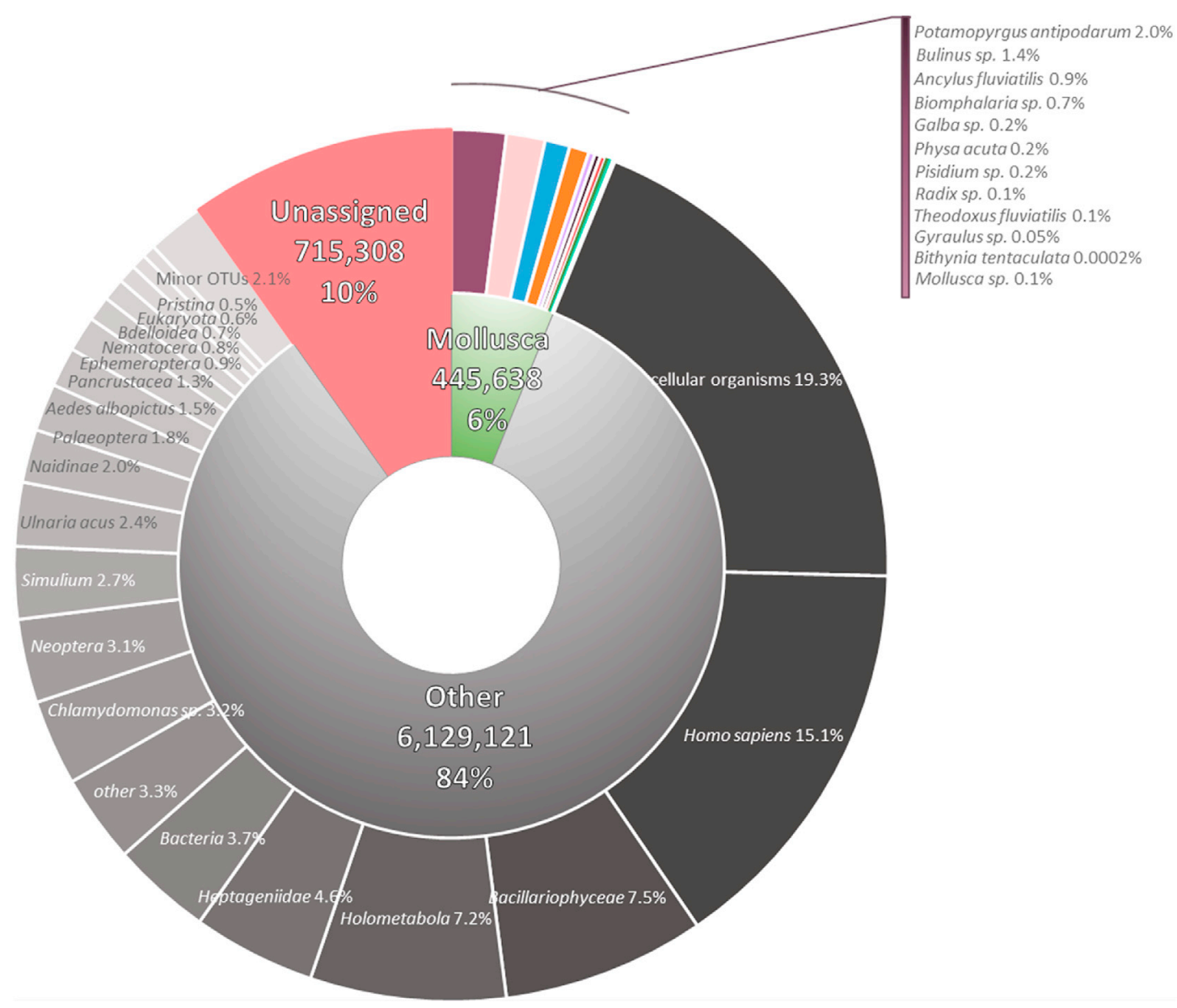

Fig. 2. Major OTUs ranking based on sequence abundances. These sequences were obtained from eDNA samples collected in the field and do not contain those from experimental controls. Each taxon is based on merged OTUs (i.e. all OTUs affiliated to a same species are merged in one category). 


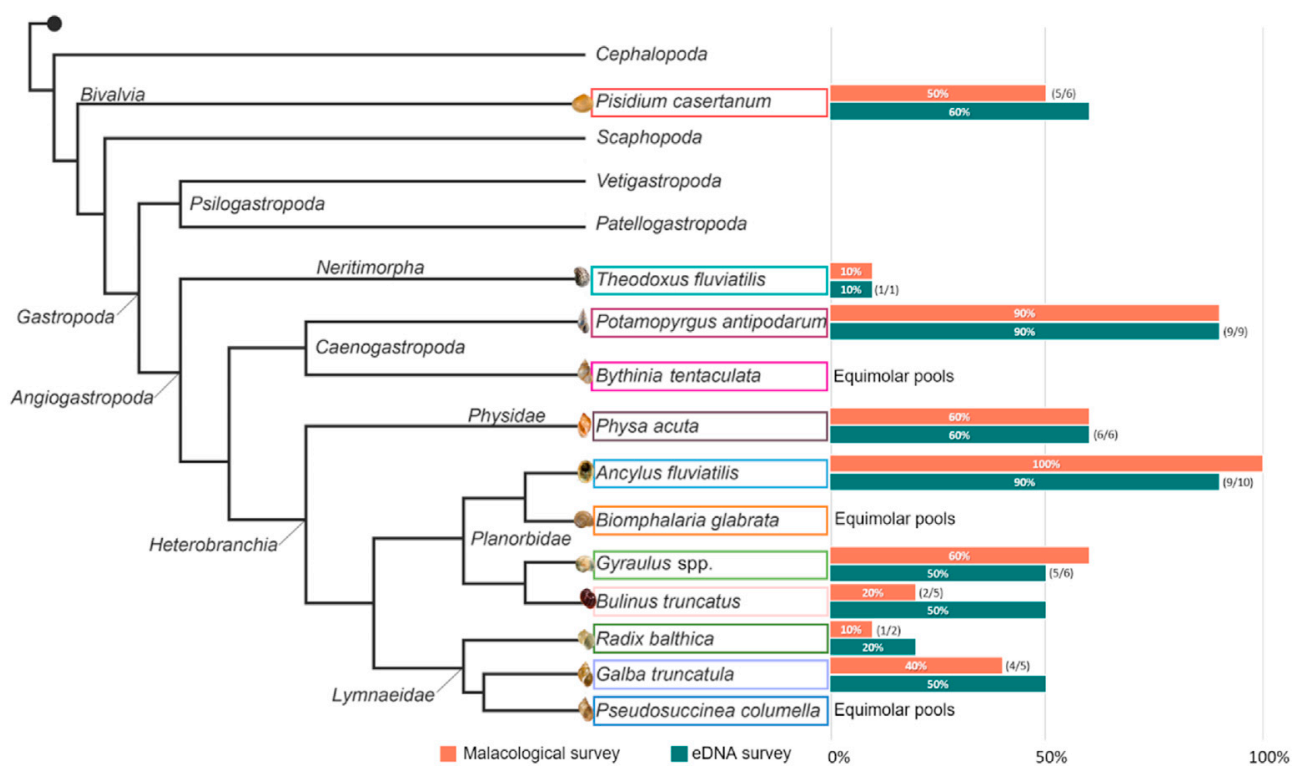

Fig. 3. Simplified phylogeny of molluscs from Cunha \& Giribet (2019) highlighting all species reported in Corsica Island during the present study and species used to test primers (mock communities). Horizontal barplots represent species occurrences recorded at the river scale $(\mathrm{N}=10)$ based on the malacological survey (in orange) and on the eDNA metabarcoding results (in blue). Numbers into brackets show the number of rivers positives for both methods on the total of positive rivers for the method showing the highest number of positive for a given species. (For interpretation of the references to colour in this figure legend, the reader is referred to the Web version of this article.)

\subsection{Comparing the malacological survey to the eDNA monitoring}

The malacological survey and the eDNA monitoring provided similar results (Figs. 3 and 4.). At the Island scale, all species identified during the malacological survey were also detected by eDNA monitoring. For some species such as the two Gyraulus species, the eDNA monitoring accuracy was limited to the genus level, one of these Gyraulus species has also not been affiliated by classical malacological survey either.

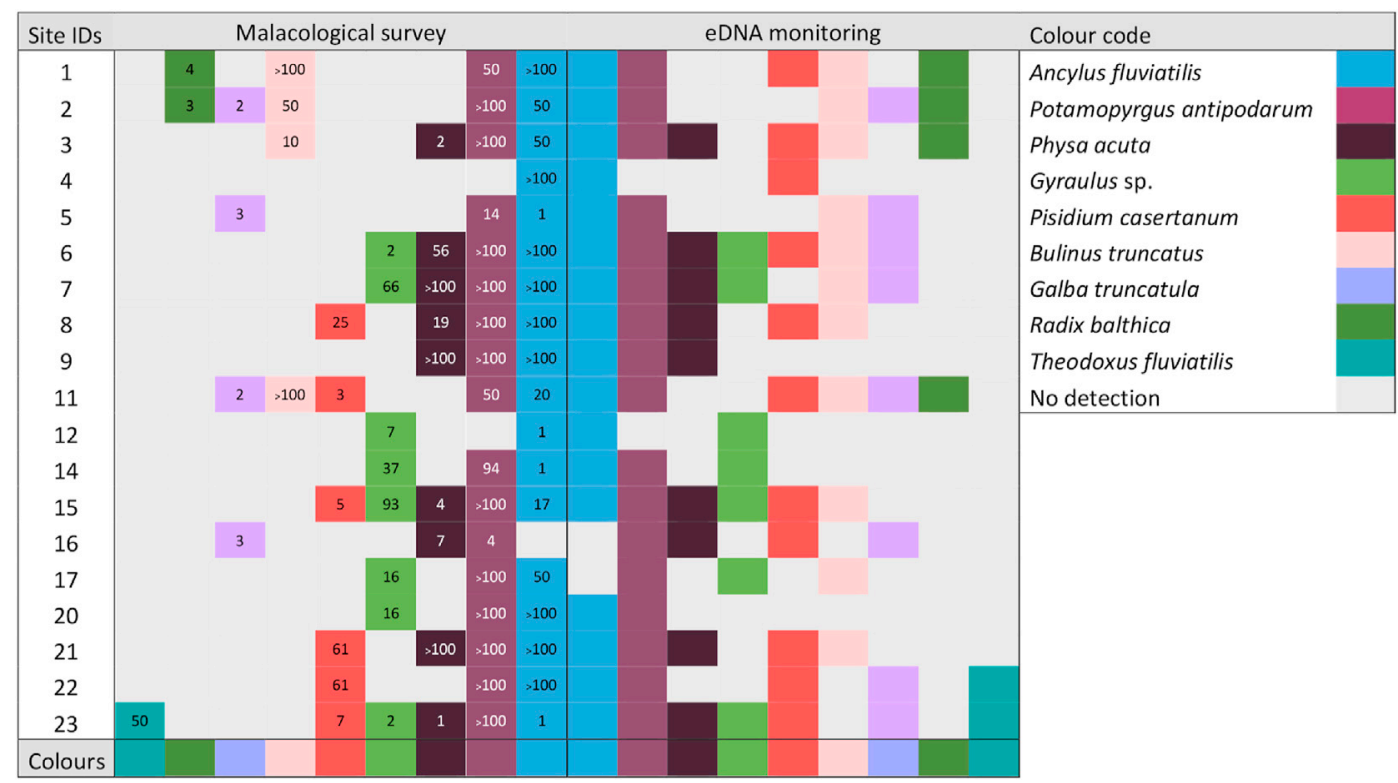

Fig. 4. Schematic representation of all detected snail species (or genera) based on the malacological survey (left side) and the eDNA monitoring tool (right side) at the 19 analyzed sites (sites 10,13,18 and 19 were discarded because of possible DNA contaminations). Columns represent species and are arranged symmetrically between the two detection methods. The number in each cell is the semi-quantitative abundance of each species at each site. 
At the site level, the eDNA monitoring confirmed the detections obtained by malacological survey for $97.1 \%$ (67/69) of the detections. Only two occurrences of A. fluviatilis (site 17) and Gyraulus sp. (site 20) detected visually during the malacological survey, were not detected by eDNA monitoring (Fig. 4). Conversely, the malacological survey confirmed the detections obtained by eDNA monitoring for 77\% (67/87) of the detections (Fig. 4). Moreover, eDNA monitoring detected on average $1.8 \pm 2.84$ more species per site than the malacological survey although this difference was not significant (Wilcoxon rank

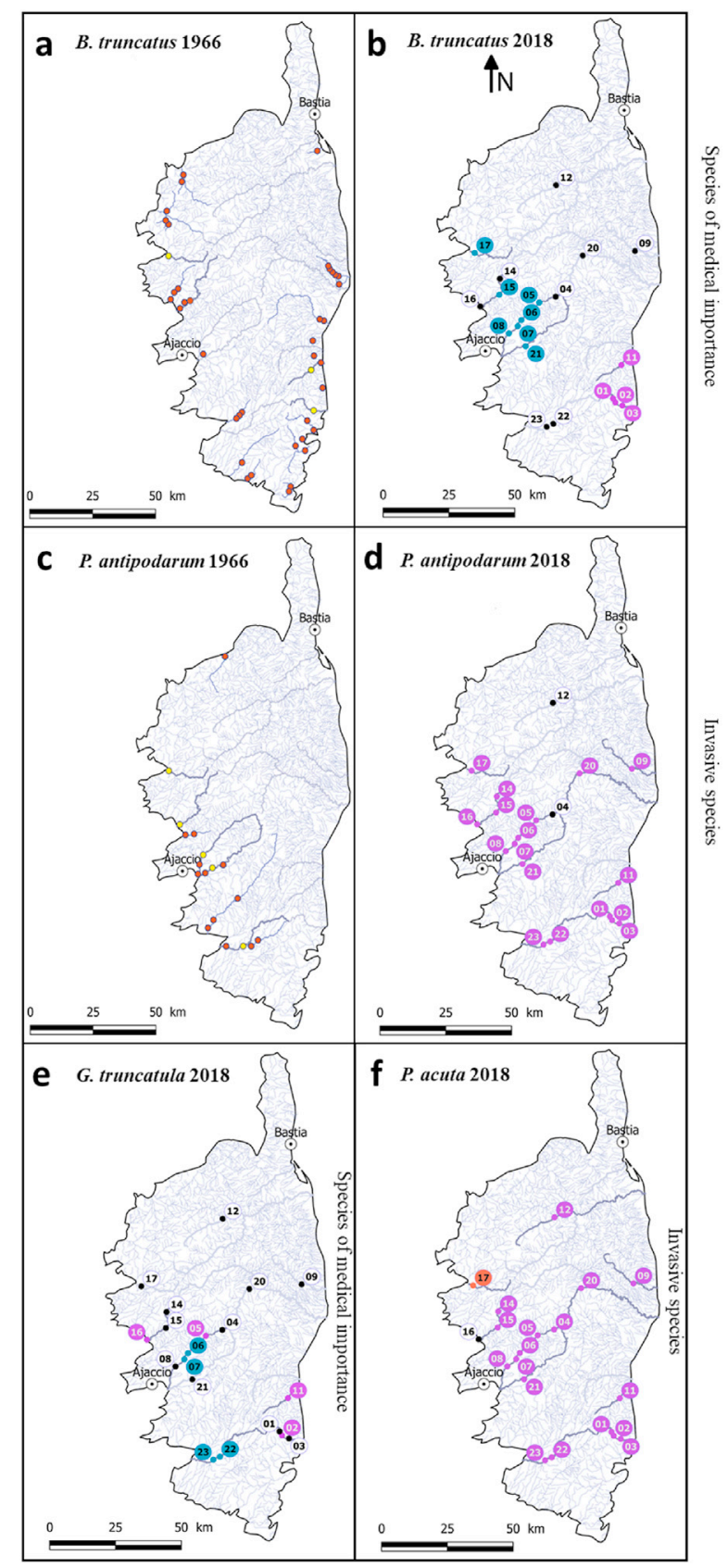

Fig. 5. Maps displaying the current and past distributions of freshwater snail species of medical/veterinary and ecological interest, a. Bulinus truncatus in 1966 , an intermediate host of the urogenital schistosomiasis infecting Humans; b. Bulinus truncatus in 2018; c. Potamopyrgus antipodarum in 1966, an invasive snail species from New Zealand; d. Potamopyrgus antipodarum in 2018; e. Galba truncatula, an intermediate host of the liver fluke infecting livestock and Humans and f. Physa acuta, an invasive snail species from North America. Black dots are sites were the given species is absent for the two monitoring methods; Purple dots are sites were the given species was detected with the two monitoring methods; Blue dots are sites were the given species was detected using the eDNA monitoring only; Orange dots are sites were the given species was detected using the malacological survey only; Yellow dots are sites were the given species was identified in our study in 2018 and in the study of Doby et al. in 1966. (For interpretation of the references to colour in this figure legend, the reader is referred to the Web version of this article.) 
test; $W=24, P=0.11$ ). Based on the eDNA approach, $B$. truncatus was detected at 11 sites while only visually detected at 4 sites (Figs. 4 \& 5b). At the river scale, the results obtained from direct malacological survey and from the eDNA monitoring approach gave even more congruent results (Fig. 3).

Among all the freshwater species detected in Corsica, two species are hosts for the transmission of trematodes of medical and veterinary importance (i.e. B. truncatus, Fig. 5b and G. truncatula, Fig. 5e) and two other are invasive species (i.e. P. antipodarum, Fig. 5d and P. acuta, Fig. 5f). The two invasive species display a wide distribution range (17 and 9 sites among the 19 monitored sites irrespective of the method) while the two species of medical/veterinary importance were mainly distributed in the Southern part of the Island. We were able to compare the current distributions of $B$. truncatus and $P$. antipodarum obtained within this study with those obtained in 1966, during previous malacological survey realized in Corsica for these two species (Doby et al., 1966a). The distribution of B. truncatus has greatly diminished over the last 60 years and is currently limited to 4 rivers of the Porto-Vecchio region (i.e. Cavu, Solenzara, Osu and Tarcu; Berry et al., 2014) for which we identified these species with the two approaches (Fig. 5a and b). Contrarily, P. antipodarum has invaded most of the sites we have prospected and is now present on the east side of Corsica (Fig. $5 \mathrm{c}$ and d).

\section{Discussion}

One of the key steps for monitoring ecosystems and to quantify the effect of anthropogenic activities on biodiversity is to develop new tools enabling rapid and exhaustive characterization of the overall intrinsic species diversity. This is particularly true for freshwater ecosystems that undergo rapid changes and that are particularly threatened nowadays (Carpenter et al., 2011). So far, the use of environmental DNA (eDNA) has been shown to be an efficient tool for monitoring fish (Hanfling et al., 2016), arthropod (Krol et al., 2019) and bivalve (Prié et al., 2020) communities in freshwater environments. Here, we present the first application of an eDNA monitoring method enabling the non-invasive characterization of entire gastropods communities from freshwater samples.

\subsection{Benchmarking the eDNA monitoring}

Our comparative approach between a classical (i.e. visual) prospection and an eDNA-based malacological survey highlights the ability of eDNA to characterize faithfully freshwater snail communities from water samples. Considering the 19 sites successfully diagnosed, 97.1\% (67/69) of total occurrences reported by the malacological survey were confirmed using eDNA monitoring. A noticeable benefit of eDNA approaches compared to malacological survey is the less time-consuming sampling effort needed per site; only one sample of $3 \mathrm{~L}$ realized by one operator ( $\approx 30 \mathrm{~min}$ from sampling to sample preservation) is needed (Mulero et al., 2020). In comparison, the time needed to realize six measure units in classical malacological survey is much longer $(>2 \mathrm{~h}$ ) depending on field practicability and experimenter skill level. However, whatever the visual taxonomical identification of specimen under binocular or the molecular lab experiment for metabarcoding are both time consuming activities. In the present study, we did not try to optimize the volume of water sampled. However, in the case of larger sampling campaigns it might be interesting to determine the lowest volume of water necessary to ensure the same diagnosis efficiency. We recently shown, using a targeted approach, that lower water volumes down to 1 L allows detecting B. truncatus without losses in efficacy (Mulero et al., 2020).

Using the eDNA monitoring approach, we tended to detect more species per site than with the malacological survey. Indeed, over the 87 detection events found using the eDNA monitoring, 77\% of them (67) were corroborated by visual observations during the malacological survey. This apparent higher richness found by eDNA metabarcoding approach compared to classical survey was already reported in previous studies (Deiner et al., 2017; Hanfling et al., 2016; Valentini et al., 2016; Prié et al., 2020). Three non-exclusive hypotheses could explain the higher efficacy of eDNA compare to classical methods. First, DNA transportation through the river flow allows collecting eDNA from upstream the targeted site. In fact, in lotic systems, eDNA is known to disperse in a given way with waterflow (Hanfling et al., 2016; Deiner et al., 2016). Second, eDNA-based methods are expected to outcompete visual surveys for detecting cryptic or rare species (e.g. Dejean et al., 2012). Cryptic freshwater mollusk species are particularly difficult to detect and previous studies estimated that about $20 \%$ of the species present at a single site are undetected after a single prospecting session during malacological surveys (Dubart et al., 2019). Moreover, detecting biases are also common in malacology because populations of snails are highly dynamic in space and time (Lamy et al., 2012). Interestingly, our eDNA approach has been particularly useful to detect $P$. casertanum compared to classical malacological survey, this species being known to be difficult to detect visually because of his preferred niche (i.e. under boulders) and its small size. Third, false positives constitute one major limitation of eDNA-based protocols (Cristescu and Hebert, 2018). These biases are generally related to either primer amplification biases or inappropriate field and/or laboratory protocols (Cristescu and Hebert, 2018). Regarding primer amplification biases, further applications of the current tool are needed to evaluate these errors considering that it is impossible to test the primers with the DNA of all known organisms in vitro. In our study, such biases are likely to be limited because our controlled mock communities were detected with no apparent amplification \& sequencing biases between species. Concerning DNA contamination, the four sites that could have been contaminated were discarded. Moreover, the detections found using eDNA monitoring yet not confirmed by malacological survey, followed an ecologically realistic distribution. For G. truncatula, the two sites found positive only by eDNA monitoring were distributed on the Gravona River, downstream from a site where $G$. truncatula was detected by the two approaches (i.e. site 5). The two other sites were distributed on the Rizzanese river in which Lymnaeid snails hosts of $F$. 
hepatica were previously identified (Gretillat, 1963). Noteworthy, this species prefers temporary water body, but could be found in river shore and associated trickle (Dreyfuss et al., 2009), which might explain the observed relatively low densities.

Regarding $B$. truncatus, the detection differences are the most noticeable between the two approaches, the seven additional sites were mainly distributed in the Gravona River and nearby rivers. For each of these rivers, $B$. truncatus was previously identified (Doby et al., 1966a). These non-randomly distributed detections in rivers were this species is historically known to be present support rather the non-detection of certain species by malacological survey, than false positive eDNA detection. However, a thorough field survey of these rivers is needed to validate our results.

\subsection{Environmental DNA for characterizing communities}

A recent study focused on freshwater bivalves has proposed an eDNA metabarcoding protocol for the characterization of these communities (Prié et al., 2020). The main differences between our study and the latter one are the volume of water sampled ( $30 \mathrm{~L}$ vs $3 \mathrm{~L}$ ) and the use of several primer combinations in the study of Prie et al. It is interesting to notice that both approaches tend to the same conclusions: eDNA detects more species than a classical malacological survey and the sensitivity of both protocols is similar. Indeed, in a single sampling, at their spatial scale Prié et al. (2020) have detected 60\% of the known bivalve community and we have found $61 \%$ of known gastropods in Corsica. Despite different protocols and different targeted groups this show replicability but also the limitation of the eDNA approach. The present eDNA metabarcoding protocol allowed to qualitatively characterize the Corsican gastropod fauna at global scale. However, as shown in previous eDNA-based metabarcoding studies, the accuracy of such characterization highly depends on the reliability of currently available databases together with sequence size that sometimes results in a limitation for the taxonomic affiliation to the genus taxonomic level especially for closely related species (Krol et al., 2019; Deiner et al., 2017). Here, we couldn't distinguish the two distinct species belonging to the Gyraulus genus identified visually. These species could also be difficult to differentiate morphologically, that could explain confusions with Planorbis planorbis on public NCBI databases. At the eDNA era, such limitations clearly call for the improvement and reinforcement of public databases aiming at characterizing biodiversity at the taxonomic and molecular scale (Henry et al., 2008; Balint et al., 2018). To this end, we submitted 6 new 16S rRNA sequences of freshwater snail species identified in Corsica. However, to overcome these limitations in the immediate future, Krol et al. (2019) recently suggested to use a combination of barcode to optimize taxonomic assignation. Recent studies also called for the need of reinforcing the collection of metadata in eDNA studies that could influence the detection of eDNA (Nicholson et al., 2020). In this way, we collected environmental variables at all sampling sites including some that are generally neglected (e.g. $\mathrm{pH}$, waterflow, water temperature; Nicholson et al., 2020). However, the sampling of a wider diversity of freshwater environment is still needed to accurately assess the effect of these variables on our ability to detect species.

\subsection{Environmental DNA for the risk assessment of parasitic diseases}

Beyond the technological development, our study provides an updated picture of the distribution of snails communities in Corsica. Among the 11 species detected, two snail species are of medical/veterinary importance. An updated distribution map for these two species is of prime interest for determining the risk of the associated waterborne diseases. In particular, in 2013 an outbreak of Schistosomiasis emerged in Corsica, this disease being caused by a trematode parasite using $B$. truncatus as host (Boissier et al., 2016; Ramalli et al., 2018). Bulinus truncatus was widely distributed in Corsica in the middle of the 20th century and at this time some authors warned authorities about the potential for such a local emergence of Schistosomiasis (Doby et al., 1966a, 1966b). Today, this species distribution is limited in four rivers in Southern Corsica (Cavu, Solenzara, Tarcu and Osu; Berry et al., 2014). Using our eDNA monitoring tool, we detected the presence of B. truncatus in the Gravona River, although possibly at low densities and/or upstream the sampled sites. This result call for an urging field validation of the local presence of this species to prevent potential transmission to Humans in this highly frequented river near Ajaccio, the main agglomeration of Corsica.

Fasciola hepatica is another trematode species already present in Corsica that uses G. truncatula as intermediate host (Oviedo et al., 1996). This parasite is responsible for the zoonotic Fasciolosis disease generally infecting livestock and Humans (Valero et al., 2002). The present study provides an up-to-date geographic distribution of G. truncatula in Corsica, hence, delineating pastures presenting a potential risk of transmission to livestock and Humans. Interestingly, the eDNA monitoring tool also detected the presence of $G$. truncatula in the Rizzanese River, a region in which lymnaeids snails hosts of $F$. hepatica were previously identified (Gretillat, 1963) although not locally detected by visual inspection in this study. In a sanitary context, these results also call for thorough monitoring of this species in this particular river.

\subsection{Environmental DNA for studying bioinvasions}

Invasive snail species needs attention as they can drastically disturb the receiving ecosystems and impact the ecology of indigenous species by altering biotic composition of invaded ecosystems (Cowie, 2001; Strayer, 2010). In this context, we have detected two invasive snail species: Physa acuta and Potamopyrgus antipodarum. Physa acuta originating from North America (Vinarski, 2017) has invaded Europe likely through the activity of aquarium keepers and maritime trade (Vinarski, 2017). Physa acuta was first reported in Corsica in 1977 (Holoyak, 2019). Today, we observe that this species has a wider distribution in Corsica than reported in public databases (Holoyak, 2019; GBIF, 2020). 
Potamopyrgus antipodarum originates from New Zealand (Goldberg et al., 2013) and has been introduced in Europe in 1859 probably via human activities such as fish farming (Alexandre da Silva et al., 2019). This parthenogenetic snail is widely distributed in Corsica and needs attention considering the important density that these populations can reach (e.g. $>400,000 /$ $\mathrm{m}^{2}$; Hall et al., 2003). This snail species is known to negatively impact nutrient cycling or can competitively exclude native species (Goldberg et al., 2013). Potamopyrgus antipodarum was first identified in Corsica in 1961 and have rapidly invaded rivers of the south-west side of the island (Doby et al., 1966a). Today, we observe that this species is widely distributed and abundant all around the island (Fig. 5d). Interestingly, the researchers that carried out the previous malacological survey hypothesized that this species could competitively exclude other freshwater snails' such as snail intermediate hosts for parasites (Doby et al., 1966a). In the same study, the authors observed that B. truncatus hosting either Schistosoma bovis (an animal parasite historically present in Corsica) or S. haematobium (a human parasite currently present in Corsica) was present all around the island. The considerable restriction of $B$. truncatus distribution in parallel with the increase distribution of $P$. antipodarum seems to agree with Doby's et al. predictions.

However, environmental metabarcoding approaches are currently limited for quantifying these interactions in natura, and more generally when they are applied for conservation, and parasitological risk assessment purposes because these study areas require not only presence/absence information but also abundance data (Yates et al., 2020). The relationship between eDNA and species abundance is subjected to unexplained variations (Yates et al., 2020) mainly because eDNA is heterogeneously released in the environment (Jo et al., 2019) and DNA persistence depend on several environmental biotic and/or abiotic factors (Barnes et al., 2014; Taberlet et al., 2018).

\section{Conclusion}

In view of these results, the eDNA monitoring using metabarcoding approaches appears particularly useful for biomonitoring studies. Here we presented the first application of eDNA metabarcoding protocol for the characterization of entire gastropods communities from water samples. This eDNA-based tool provides very similar results when compared to the classical malacological survey and is useful for the detection of habitat hosting whether invasive snail species or species of medical and veterinary importance, while requiring fewer sampling efforts than the visual prospecting. Beyond these qualitative data, our results have given more support to previous hypotheses about a potential competitive interaction between $B$. truncatus and P. antipodarum. Indeed, this interaction needs to be experimentally validated but could play an important role in the endemization process of the urogenital bilharziasis in Corsica. Hence, the environmental metabarcoding is particularly suited for a first analysis of environments for which data on malacofauna are scarce. In a regular use context, the temporality of records could enable an accurate characterization of local snail communities in space and time leading to the early detection of phenomena such as biological invasions, biodiversity losses, and hence, paving the way for complementary studies in other fields.

\section{Authors contributions}

JB., OR. and SM. conceived the study and the sampling design. AL., MZ., JF., YQ and SM. carried out the malacological survey and the field sampling. SM., JFA. and ET. processed the samples and performed molecular experiments and amplicon sequencing. SM., JB., OR. and ET., analyzed and interpreted the data. JPP. provided the malacological expertise. SM., JB. and OR. drafted the manuscript. JB., OR., SM., ET., AL., MZ., JFA., JF., YQ. and JPP. revised the manuscript. All authors read and approved the final manuscript.

\section{Funding}

This study was funded by the Région Occitanie, the European "Fonds Européen de Développement Régional" (FEDER); the French Agency for Food, Environmental and Occupational Health \& Safety (ANSES) [PNREST 2019/1/059 Molrisk]; and the French "Agence Nationale de la Recherche" (ANR) [Program HySWARM ANR-18-CE35-0001].

\section{Availability of data and materials}

The dataset supporting the conclusions of this article is included within the article.

\section{Declaration of competing interest}

The authors declare that they have no known competing financial interests or personal relationships that could have appeared to influence the work reported in this paper.

\section{Acknowledgements}

We thank the French agency "Agence Régionale de Santé de Corse" (ARS) for the data relative to the prospected sites. This study is set within the framework of the "Laboratoire d'Excellence (LABEX)" TULIP (ANR-10-LABX-41). 


\section{Appendix A. Supplementary data}

\section{Supplementary data to this article can be found online at https://doi.org/10.1016/j.gecco.2020.e01428.}

\section{References}

Alexandre Da Silva, M.V., Nunes Souza, J.V., Souza, J.R.B., Vieira, L.M., 2019. Modelling species distributions to predict areas at risk of invasion by the exotic aquatic New Zealand mudsnail Potamopyrgus antipodarum (Gray 1843). Freshw. Biol. 64, 1504-1518.

Ars, 2019. Qualité des eaux de baignade [Online]. French minister for Solidarity and Health: French minister for Solidarity and Health. Available. http:// baignades.sante.gouv.fr/baignades/navigMap.do?idCarte=fra\#a. Accessed November 28, 20192019.

Balian, E.V., Segers, H., Lévèque, C., Martens, K., 2008. The freshwater animal diversity assessment: an overview of the results. Hydrobiologia 595, 627-637.

Balint, M., Nowak, C., Marton, O., Pauls, S.U., Wittwer, C., Aramayo, J.L., Schulze, A., Chambert, T., Cocchiararo, B., Jansen, M., 2018. Accuracy, limitations and cost efficiency of eDNA-based community survey in tropical frogs. Mol Ecol Resour 18, 1415-1426.

Barnes, M.A., Turner, C.R., Jerde, C.L., Renshaw, M.A., Chadderton, W.L., Lodge, D.M., 2014. Environmental conditions influence eDNA persistence in aquatic systems. Environ. Sci. Technol. 48, 1819-1827.

Berry, A., Mone, H., Iriart, X., Mouahid, G., Aboo, O., Boissier, J., Fillaux, J., Cassaing, S., Debuisson, C., Valentin, A., Mitta, G., Theron, A., Magnaval, J.F., 2014. Schistosomiasis haematobium, Corsica, France. Emerg. Infect. Dis. 20, 1595-1597.

Blettler, M.C.M., Abrial, E., Khan, F.R., Sivri, N., Espinola, L.A., 2018. Freshwater plastic pollution: recognizing research biases and identifying knowledge gaps. Water Res. 143, 416-424.

Bohmann, K., Evans, A., Gilbert, M.T., Carvalho, G.R., Creer, S., Knapp, M., Yu, D.W., De Bruyn, M., 2014. Environmental DNA for wildlife biology and biodiversity monitoring. Trends Ecol. Evol. 29, 358-367.

Boissier, J., Grech-Angelini, S., Webster, B.L., Allienne, J.F., Huyse, T., Mas-Coma, S., Toulza, E., Barre-Cardi, H., Rollinson, D., Kincaid-Smith, J., Oleaga, A., Galinier, R., Foata, J., Rognon, A., Berry, A., Mouahid, G., Henneron, R., Mone, H., Noel, H., Mitta, G., 2016. Outbreak of urogenital schistosomiasis in Corsica (France): an epidemiological case study. Lancet Infect. Dis. 16, 971-979.

Bouchet, P., Falkner, G., Seddon, M.B., 1999. Lists of protected land and freshwater molluscs in the Bern Convention and European Habitats Directive: are they relevant to conservation? Biol. Conserv. 90, 21-31.

Carpenter, S.R., Stanley, E.H., Vander Zanden, M.J., 2011. State of the world's freshwater ecosystems: physical, chemical, and biological changes. Annu. Rev. Environ. Resour. 36, 75-99.

Clusa, L., Miralles, L., Basanta, A., Escot, C., Garcia-Vazquez, E., 2017. eDNA for detection of five highly invasive molluscs. A case study in urban rivers from the Iberian Peninsula. PloS One 12, e0188126.

Cowie, R., 2001. Invertebrate invasions on Pacific Islands and the replacement of unique native faunas: a synthesis of the land and freshwater snails. Biol. Invasions 3, 119-136.

Cristescu, M.E., Hebert, P.D.N., 2018. Uses and misuses of environmental DNA in biodiversity science and conservation. Annu. Rev. Ecol. Evol. Syst. 49, 209-230.

Deiner, K., Bik, H.M., Machler, E., Seymour, M., Lacoursiere-Roussel, A., Altermatt, F., Creer, S., Bista, I., Lodge, D.M., De Vere, N., Pfrender, M.E., Bernatchez, L., 2017. Environmental DNA metabarcoding: transforming how we survey animal and plant communities. Mol. Ecol. 26, $5872-5895$.

Deiner, K., Fronhofer, E.A., Machler, E., Walser, J.C., Altermatt, F., 2016. Environmental DNA reveals that rivers are conveyer belts of biodiversity information. Nat. Commun. 7, 12544

Dejean, T., Valentini, A., Miquel, C., Taberlet, P., Bellemain, E., Miaud, C., 2012. Improved detection of an alien invasive species through environmental DNA barcoding: the example of the American bullfrog Lithobates catesbeianus. J. Appl. Ecol. 49, 953-959.

Dillon, R., 2000a. Gastropod autecology. In: Dillon, R.T. (Ed.), The Ecology of Freshwater Molluscs. Cambridge University Press, Cambridge.

Dillon, R.T., 2000b. Predation. In: Dillon, R.T. (Ed.), The Ecology of Freshwater Molluscs. Cambridge University Press, Cambridge.

Doby, J.M., Rault, B., Deblock, S., Chabaud, A., 1966a. Bullins et bilharzioses en Corse. Ann. Parasitol. Hum. Comp. 41, 337-349.

Doby, J.M., Rault, B., Deblock, S., Chabaud, A., 1966b. Snails and bilharziasis in Corsica. Distribution, frequency and biology of "Bulinus truncatus". Ann. Parasitol. Hum. Comp. 41, 337-349.

Dreyfuss, G., Vareille-Morel, V., Rondelaud, D., 2009. Les habitats de Lymnaea truncatula Müller (Mollusque) le long de deux rivières. Annales de Limnologie - Int. J. Limnol. 33, 67-72.

Dubart, M., Pantel, J.H., Pointier, J.P., Jarne, P., David, P., 2019. Modeling competition, niche, and coexistence between an invasive and a native species in a two-species metapopulation. Ecology 100, e02700.

Escudie, F., Auer, L., Bernard, M., Mariadassou, M., Cauquil, L., Vidal, K., Maman, S., Hernandez-Raquet, G., Combes, S., Pascal, G., 2018. FROGS: Find, rapidly, OTUs with Galaxy solution. Bioinformatics 34, 1287-1294.

Fornillos, R.J.C., Sato, M.O., Tabios, I.K.B., Sato, M., Leonardo, L.R., Chigusa, Y., Minamoto, T., Kikuchi, M., Legaspi, E.R., Fontanilla, I.K.C., 2019. Detection of Schistosoma japonicum and Oncomelania hupensis quadrasi environmental DNA and its potential utility to schistosomiasis japonica surveillance in the Philippines. PloS One 14, e0224617.

GBIF, 2020. The global biodiversity information facility [online]. Available: https://www.gbif.org/what-is-gbif. Accessed November 26 2020.

Goldberg, C.S., Sepulveda, A., Ray, A., Baumgardt, J., Waits, L.P., 2013. Environmental DNA as a new method for early detection of New Zealand mudsnails (Potamopyrgus antipodarum). Freshw. Sci. 32, 792-800.

Gretillat, S., 1963. [Epidemiology of certain trematode diseases of domestic animals in Corsica (bovine bilharziosis and bovine and ovine distomiasis). Observations conducted during a mission accomplished during the autumn of 1962]. Ann. Parasitol. Hum. Comp. 38, $471-481$.

Hall, R., Tank, J., Dybdahl, M., 2003. Exotic snails dominate nitrogen and carbon cycling in a highly productive stream. Front. Ecol. Environ. 1, 407-411.

Hanfling, B., Lawson Handley, L., Read, D.S., Hahn, C., Li, J., Nichols, P., Blackman, R.C., Oliver, A., Winfield, I.J., 2016. Environmental DNA metabarcoding of lake fish communities reflects long-term data from established survey methods. Mol. Ecol. 25, 3101-3119.

Henry, P.-Y., Lengyel, S., Nowicki, P., Julliard, R., Clobert, J., Čelik, T., Gruber, B., Schmeller, D.S., Babij, V., Henle, K., 2008. Integrating ongoing biodiversity monitoring: potential benefits and methods. Biodivers. Conserv. 17, 3357-3382.

Hill, W.R., Griffiths, N.A., 2017. Nitrogen processing by grazers in a headwater stream: riparian connections. Freshw. Biol. 62, 17-29.

Holoyak, D.T., 2019. Inventaire National du Patrimoine Naturel (2019). Données de malacologie continentale transmises par D. T. Holoyak \& M. B. Seddon. Version 1.1. UMS PatriNat (OFB-CNRS-MNHN), Paris. Occurrence dataset. https://doi.org/10.15468/wwdhh0. Accessed via GBIF.org on November 26 2020.

INPN, 2020. National Inventory of natural heritage [online]. Muséum national d'Histoire naturelle. Available: https://inpn.mnhn.fr. Accessed February 11 2020.

IUCN, 2020. International Union for Conservation of nature [online]. International union for conservation of nature. Available: www.iucn.org. Accessed February 102020.

Janssen, J.A.M., Rodwell, J.S., Garcia-Criado, S., Gubbay, S., Haynes, T., Nieto, A., Sanders, N., Landucci, F., Loidi, J., Ssymank, A., Valachovič, M., 2016. European Red List of Habitats Part 2. Terrestrial and Freshwater Habitats, vol. 2. European Publications Office.

Jo, T., Murakami, H., Yamamoto, S., Masuda, R., Minamoto, T., 2019. Effect of water temperature and fish biomass on environmental DNA shedding, degradation, and size distribution. Ecol Evol 9, 1135-1146.

Johnson, P.D., Bogan, A.E., Brown, K.M., Burkhead, N.M., Cordeiro, J.R., Garner, J.T., Hartfield, P.D., Lepitzki, D.A.W., Mackie, G.L., Pip, E., Tarpley, T.A., Tiemann, J.S., Whelan, N.V., Strong, E.E., 2013. Conservation status of freshwater gastropods of Canada and the United States. Fisheries 38, $247-282$. 
Jones, K.E., Patel, N.G., Levy, M.A., Storeygard, A., Balk, D., Gittleman, J.L., Daszak, P., 2008. Global trends in emerging infectious diseases. Nature 451, 990-993.

Jones, R.A., Brophy, P.M., Davis, C.N., Davies, T.E., Emberson, H., Rees Stevens, P., Williams, H.W., 2018. Detection of Galba truncatula, Fasciola hepatica and Calicophoron daubneyi environmental DNA within water sources on pasture land, a future tool for fluke control? Parasites Vectors $11,342$.

Jones, R.A., Williams, H.W., Dalesman, S., Brophy, P.M., 2015. Confirmation of Galba truncatula as an intermediate host snail for Calicophoron daubneyi in Great Britain, with evidence of alternative snail species hosting Fasciola hepatica. Parasites Vectors 8, 656.

Kincaid-Smith, J., Rey, O., Toulza, E., Berry, A., Boissier, J., 2017. Emerging schistosomiasis in Europe: a need to quantify the risks. Trends Parasitol. 33, 600-609.

Krol, L., Van Der Hoorn, B., Gorsich, E.E., Trimbos, K., Bodegom, P.M.V., Schrama, M., 2019. How does eDNA compare to traditional trapping? Detecting mosquito communities in South-african freshwater ponds. Front. Ecol. Evol. 7, 260.

Lamy, T., Pointier, J.P., Jarne, P., David, P., 2012. Testing metapopulation dynamics using genetic, demographic and ecological data. Mol. Ecol. 21, 1394-1410.

Longmire, J.L., Maltbie, M., Baker, R.J., 1997. Use of "lysis buffer. In: DNA Isolation and its Implication for Museum Collections. Museum of Texas Tech University. https://doi.org/10.5962/bhl.title.143318.

Lu, X.T., Gu, Q.Y., Limpanont, Y., Song, L.G., Wu, Z.D., Okanurak, K., Lv, Z.Y., 2018. Snail-borne parasitic diseases: an update on global epidemiological distribution, transmission interruption and control methods. Infect Dis Poverty 7, 28.

Lydeard, C., Cowie, R.H., Ponder, W.F., Bogan, A.E., Bouchet, P., Clark, S.A., Cummings, K.S., Frest, T.J., Gargominy, O., Herbert, D.G., Hershler, R., Perez, K.E., Roth, B., Seddon, M., Strong, E.E., Thompson, F.G., 2004. The global decline of nonmarine mollusks. Bioscience 54, $321-330$.

Macher, J.N., Vivancos, A., Piggott, J.J., Centeno, F.C., Matthaei, C.D., Leese, F., 2018. Comparison of environmental DNA and bulk-sample metabarcoding using highly degenerate cytochrome c oxidase I primers. Mol Ecol Resour 18, 1456-1468.

Miralles, L., Parrondo, M., Hernandez De Rojas, A., Garcia-Vazquez, E., Borrell, Y.J., 2019. Development and validation of eDNA markers for the detection of Crepidula fornicata in environmental samples. Mar. Pollut. Bull. 146, 827-830.

Mouthon, J., 1982. Les mollusques dulcicoles - données biologiques et écologiques - clés de détermination des principaux genres de bivalves et de gastéropodes de France. Bull. Français de Piscicult. 1-27.

Mulero, S., Boissier, J., Allienne, J., Quilichini, Y., Foata, J., Pointier, J., Rey, O., 2020. Environmental DNA for detecting Bulinus truncatus: a new environmental surveillance tool for schistosomiasis emergence risk assessment. Environ. DNA 2, 161-174.

Nicholson, A., Mcisaac, D., Macdonald, C., Gec, P., Mason, B.E., Rein, W., et al., 2020. An analysis of metadata reporting in freshwater environmental DNA research calls for the development of best practice guidelines. Environ. DNA. https://doi.org/10.1002/edn3.81.

Oviedo, J.A., Bargues, M.D., Mas-Coma, S., 1996. The intermediate snail host of Fasciola hepatica on the mediterranean island of Corsica. APEX 56, 217-220.

Parmesan, C., Yohe, G., 2003. A globally coherent fingerprint of climate change impacts across natural systems. Nature 421, $37-42$.

Pedersen, M.W., Overballe-Petersen, S., Ermini, L., Sarkissian, C.D., Haile, J., Hellstrom, M., Spens, J., Thomsen, P.F., Bohmann, K., Cappellini, E., Schnell, I.B., Wales, N.A., Caroe, C., Campos, P.F., Schmidt, A.M., Gilbert, M.T., Hansen, A.J., Orlando, L., Willerslev, E., 2015. Ancient and modern environmental DNA. Philos. Trans. R. Soc. Lond. B Biol. Sci. 370, 20130383.

Prié, V., Valentini, A., Lopes-Lima, M., Froufe, E., Rocle, M., Poulet, N., Taberlet, P., Dejean, T., 2020. Environmental DNA metabarcoding for freshwater bivalves biodiversity assessment: methods and results for the Western Palearctic (European sub-region). Hydrobiologia. https://doi.org/10.1007/s10750-02004260-8.

Ramalli, L., Mulero, S., Noel, H., Chiappini, J.D., Vincent, J., Barre-Cardi, H., Malfait, P., Normand, G., Busato, F., Gendrin, V., Allienne, J.F., Fillaux, J., Boissier, J., Berry, A., 2018. Persistence of schistosomal transmission linked to the Cavu river in southern Corsica since 2013. Euro Surveill. 23, 2-5.

Rognes, T., Flouri, T., Nichols, B., Quince, C., Mahe, F., 2016. VSEARCH: a versatile open source tool for metagenomics. PeerJ 4 , e2584.

Saito, T., Hirano, T., Prozorova, L., Tu Do, V., Sulikowska-Drozd, A., Sitnikova, T., Surenkhorloo, P., Yamazaki, D., Morii, Y., Kameda, Y., Fukuda, H., Chiba, S., 2018. Phylogeography of freshwater planorbid snails reveals diversification patterns in Eurasian continental islands. BMC Evol. Biol. $18,164$.

Strayer, D.L., 2010. Alien species in fresh waters: ecological effects, interactions with other stressors, and prospects for the future. Freshw. Biol. 55 (Suppl. 1), $152-174$.

Strayer, D.L., Dudgeon, D., 2010. Freshwater biodiversity conservation: recent progress and future challenges. J. North Am. Benthol. Soc. 29, 344-358.

Strong, E.E., Gargominy, O., Ponder, W.F., Bouchet, P., 2007. Global diversity of gastropods (Gastropoda; Mollusca) in freshwater. Hydrobiologia 595, 149-166.

Taberlet, P., Bonin, A., Zinger, L., Coissac, E., 2018. Environmental DNA: for Biodiversity Research and Monitoring. Oxford University Press, Oxford, UK.

Taberlet, P., Coissac, E., Hajibabaei, M., Rieseberg, L.H., 2012. Environmental DNA. Mol. Ecol. 21, 1789-1793.

Tallarico, L.D.F., 2016. Freshwater gastropods as a tool for ecotoxicology assessments in Latin America*. Am. Malacol. Bull. 33, 330-336.

Valentini, A., Taberlet, P., Miaud, C., Civade, R., Herder, J., Thomsen, P.F., Bellemain, E., Besnard, A., Coissac, E., Boyer, F., Gaboriaud, C., Jean, P., Poulet, N., Roset, N., Copp, G.H., Geniez, P., Pont, D., Argillier, C., Baudoin, J.M., Peroux, T., Crivelli, A.J., Olivier, A., Acqueberge, M., Le Brun, M., Moller, P.R., Willerslev, E., Dejean, T., 2016. Next-generation monitoring of aquatic biodiversity using environmental DNA metabarcoding. Mol. Ecol. 25, 929-942.

Valero, M.A., Panova, M., Comes, A.M., Fons, R., Mas-Coma, S., 2002. Patterns in size and shedding of Fasciola hepatica eggs by naturally and experimentally infected murid rodents. J. Parasitol. 88, 308-313.

Vinarski, M.V., 2017. The history of an invasion: phases of the explosive spread of the physid snail Physella acuta through Europe, Transcaucasia and Central Asia. Biol. Invasions 19, 1299-1314.

Vinarski, M.V., Kramarenko, S.S., 2015. How does the discrepancies among taxonomists affect macroecological patterns? A case study of freshwater snails of Western Siberia. Biodivers. Conserv. 24, 2079-2091.

Waldron, A., Miller, D.C., Redding, D., Mooers, A., Kuhn, T.S., Nibbelink, N., Roberts, J.T., Tobias, J.A., Gittleman, J.L., 2017. Reductions in global biodiversity loss predicted from conservation spending. Nature 551, 364-367.

Yates, M.C., Glaser, D.M., Post, J.R., Cristescu, M.E., Fraser, D.J., Derry, A.M., 2020. The relationship between eDNA particle concentration and organism abundance in nature is strengthened by allometric scaling. Mol. Ecol. 1-15, 2020;00. 